\title{
THE LEGAL ASPECT OF INDUSTRIAL RELATIONS PRACTICE IN BANGLADESH
}

\author{
Tasnuva Mahbub Chowdhury \\ School of Law, UUM COLGIS, Universiti Utara Malaysia, Malaysia. \\ E-mail: tasnuva.mahbub@gmail.com \\ Mohammed Rahel \\ School of Law, UUM COLGIS, Universiti Utara Malaysia, Malaysia. \\ E-mail: rahelecon1@gmail.com
}

\begin{abstract}
The role of labour and industrial laws is of paramount importance when the economy of a country depends largely on its industrial sector. In addition, the necessary infrastructure for investments in natural resources is also important. It is clear that if these essential elements are not available then the growth of the industrial sector is hardly feasible. Besides all these, the proper management of labour is essential for the growth of the industrial sector including managing labour issues. Thus timely disposal of labour disputes is also important. However, in most cases labour law disputes are not solved within a short period of time causing remedies which are essential for these disputes to be delayed. Labour laws are important from the Bangladesh perspective as it is crucial for the industrial development of the country. Labour is an important part of an industry and as such an industry without labour would be inconceivable. Although labour rights are crucial in Bangladesh, employees are ignorant about their rights as they do not have adequate education and knowledge about labour laws. This is a huge problem. This paper aims to narrow the gap between existing laws and the real scenario relating to industrial practices in Bangladesh.
\end{abstract}

Keywords: Industrial relations, Disputes, Employers, Employees, Labour.

Abstrak: Peranan undang-undang buruh dan perindustrian sangat penting. Kita tahu bahawa keadaan ekonomi sesebuah negara sangat bergantung kepada sektor industri. Tambahan lagi, infrastruktur untuk pelaburan terhadap sumber asli sangat pernting kerana tanpanya, perkembangan sektor industri adalah mustahil. Selain itu, isu-isu 
pekerja juga memainkan peranan penting. Pengurusan buruh yang betul sangat penting dalam memperkembangkan sektor industri. Pengurusan yang teratur dalam pertikaian buruh juga penting. Dapat dilihat bahawa kes-kes yang melibatkan pertikaian buruh tidak diselesaikan dalam waktu yang singkat. Maka, undangundang buruh adalah penting dalam perkembangan sektor industri di Bangladesh kerana pekerja-pekerja merupakan tulang belakang bagi pembangunan industri. Sesebuah industri tidak mungkin membangun tanpa pekerja-pekerja. Hak-hak pekerja adalah sangat penting, namun di Bangladesh, pekerja-pekerja tidak tahu ataupun mengendahkan hak-hak mereka. Mereka tidak tahu berkenaan undang-undang buruh kerana kurang pendidikan. Article ini bertujuan untuk meningkatkan jurang antara undang-undang sedia ada dengan kejadian sebenar yang berkaitan dengan amalan perindustrian di Bangladesh.

Kata Kunci: Hubungan industri, Pertikaian, Majikan-majikan, Pekerja-pekerja, Buruh.

\section{INTRODUCTION}

The connection between employer and employee or trade union is called Industrial Relations (IR). A harmonious relationship is essential for the employer and employee to protect the interests of both parties of creation. Keeping in mind the end goal to maintain good association with workers, the fundamental elements of each association ought to maintain a strategic distance from any question with them or to settle it ahead of schedule as conceivable in order to guarantee industrial peace and profitability.

In other words, good industrial relations imply industrial peace which is essential for better and higher creations. IR might be comprehended in both bury and intra terms that is employers and employees, employees and employers and also employers and employers. Such assorted relations are the result of present-day modern industrial practices; involving a tremendous assemblage of aggregate work including the corporate labour of countless parties in a venture. In every one of these relations, however, the one between employers and employees is of fundamental significance under the arrangement of entrepreneur relations of creation. 
IR is concerned about assurance of wages and states of work. IR and human relations are unmistakably two key factors in industry, one relying on the other. Great modern relations provide the fundamental foundation to human relations. In any endeavour, great relations between the administration and employees rely on the level of shared certainty which can be set up. This relies on the acknowledgement by the employees of the generosity and honesty of the administration in the everyday treatment of inquiries, which are of shared concern. ${ }^{1}$

The main imperative for the advancement of good industrial relations is a decent labour policy. The point of such a strategy ought to be to secure the ideal co-operation of the employees. Each employee ought to have the chance to contribute his administrations, as well as his recommendations and thoughts towards the normal exertion. The objectives of good industrial relations ought to be the advancement and advance of the industry through equitable strategies, and steadiness which add up to prosperity and bliss of the workers and industrial peace. Hence, industrial peace is the product of good industrial relations. ${ }^{2}$

Hindrances to the convenient determination of labour debate include two sorts of issues; one is the legal boundary and the other is the useful one. To manage the first, we start by sketching out the source of Labour Courts, its constitution, organisation, forces and methodology, including the Labour Appellate Tribunal, as the apparatus for the transfer of different sorts of labour cause. This layout is then trailed by a short record for the regional and other jurisdictional parts of the Labour Court. ${ }^{3}$

\section{INDUSTRIAL RELATIONS SCENARIOS IN BANGLADESH}

In Bangladesh, the nature and part of exchange unions change from segment to division, industry to industry, and area to district.

$1 \quad$ Ahmed, S. (1993). Measures to increase the contribution of vocational training for employment generation and poverty alleviation: the experience of BRAC, paper presented at the national seminar on Role of Vocational Training towards Human Resource Development in Bangladesh, Dhaka: 17-20 July.

2 Clark, I. and Mueller, F. (1996).Organizations and Nations: from Universalism to Institutionalism, British Journal of Management, Vol. 7, pp.125-139.

3 Coller, X. and Marginson, P. (1998). Channels of Influences over Employment Practice in MNCs: A Case from the Food Industry, Industrial Relations Journal, Vol. 29, No. 1, pp. 4-17. 
Aggregate bartering on pay and remittances is illegal in general society (Robinson, 1996) as the legislature decides a solitary arrangement of uniform pay scales and stipends for all people in general division endeavours. ${ }^{4}$

Trade unions deal with current conflicts and extraordinary issues like the use of labour laws, change of working conditions, choice of welfare programming specialists of the employees and guidelines and getting ready the workers. ${ }^{5}$ This degree of total wheeling and dealing of issues compel the trade unions to forge links with the influential performing craftsman i.e. the government, to achieve their targets and as needs are, industrial relations incorporate participation between political social affairs and trade unions rather than an association between a huge business organisation and worker agents. ${ }^{6}$

The brought together structure of pay; wheeling and dealing among individuals, by and large, part affiliations make it hard to interface the remuneration, which therefore brings inefficient viewpoints and

affiliations lose their forcefulness as time goes by. ${ }^{7}$ In the private zone, an extensive variety of total bargaining occurs at the endeavour level between the organisation and the union. ${ }^{8}$ The affirmation of employee's relationship with the ultimate objective of total wheeling and dealing depends upon each business and the nature of specialist's affiliation stress.

In the private section, modern relations process is consistently annoyed by links among private and open division unions and the effect connected by continually going back to the past. The annoyed violence when all is said in done society part as often as possible

4 Khan, M. N.(1996).Labour Administration: Profile on Bangladesh, International Labour Organization Area Office, Dhaka: Bangladesh.

5 Talukdar, M. (1996).Labour and Industry, Dhaka: Nasa Publishers.

6 Ahmad, M. (1989). Transnational Corporations from Asian and Pacific Developing Economies in Bangladesh, Bangladesh Journal of Political Economy, Vol.19, No. 2, pp. 340-384.

7 Akkas, M. A. (1998). Labour Management Co-operation: The Bangladesh Perspectives, Dhaka University Journal of Business Studies, Vol. 19, No. 2, pp. 117-145.

8 Khan, M. N. (1996).Labour Administration: Profile on Bangladesh, International Labour Organization Area Office, Dhaka: Bangladesh. 
floods to incorporating restrictive preparing plants. Standards for the establishment of a Premium Committee in every establishment where no less than 50 workers are used, with meet amount of master's and managerial representatives are given by the IRO 1969, yet eventually, few endeavours have introduced 'Venture Committees', and where they have, these frameworks purportedly serve an unimportant part at the plant level. ${ }^{9}$

Most of the employers see such investments as an encroachment of their rights and benefits, trade unions consider these sheets of trustees as a sort of parallel affiliation which may undermine their feasibility, and assume that the components of such chambers impose commitments, responsibilities and obligations on them without looking at points of interest and choice in the organisation. ${ }^{10}$

As a result of close business-authoritative issues associates in Bangladesh, the first managers in Bangladesh (essentially two or three hundred people beginning with just a few families) control and direct the economy, laws and the governing body with everything taken into account. The calm features of present current relations circumstance in Bangladesh are at present discussed. ${ }^{11}$

\section{Objectives of Industrial Relations}

The objectives of industrial relations are:

i. To protect the enthusiasm of employees and management by securing the most elevated amount of shared understanding and co-operative attitude among each of those areas in the industry which takes an interest during the time spent creating.

ii. To keep away from modern clash or strife and create agreeable relations, which are fundamental factors for the profitability of employees and the advancement of a nation.

9 Monowar Hossain Mahmood, (2008). Sharing the Pie: Trade Unionism and Industrial Relations in Multinationals in Bangladesh, Sri Lankan Journal of Human Resource Management, Vol.2, No. 1.

10 Khan, M. N. (1996). Labour Administration: Profile on Bangladesh, International Labour Organization Area Office, Dhaka: Bangladesh.

11 Khan, A. A., and Taher, M. A. (2008). Human Resource Management and Industrial Relations. Dhaka, Bangladesh: Abir Publications. 
iii. To step up efficiency of full-time work by diminishing the inclination for high turnover and recurrence of nonattendance.

iv. To nurture the development of an industrial democracy in light of the labour organisation in the sharing of benefits and administrative choices.

v. To dispense with, to an extent which is conceivable and practicable, strikes, lockouts and gheraos by giving sensible wages, enhanced living and working conditions; specified incidental advantages.

vi. To step up government control of plants and units which are running at a loss or in which creations must be managed by people in general.

vii. To improve the financial state of workers in the current administration and political government.

viii. To restrain practices by the state on modern endeavours with a view to controlling creations and advancing harmonious industrial relations.

The source and development of labour law might be credited for the most part to the advancement of sought out industries where countless including women and young adults are utilized under conditions which have a tendency to be adverse to their well-being and welfare. From recorded perspective labour law has brought forth some central modern rights in the field of generation. In the meantime, it has likewise given protection for those rights.

\section{LOOPHOLES OF EXISTING LAWS}

The loopholes of existing laws and the weak performance of courts frustrate the aggrieved persons. By and large, to arrange a case in the Labour Tribunal is 60 days. However, around 50 percent of the cases takes a day or between two to three years. The time required for 25 percent of the cases was between three and five years. Around eight for every penny of the cases took over five years. The normal time taken to choose the cases by the First Labour Court and the Second Labour Court of Dhaka was more than 17.5 months and 31 months, respectively. ${ }^{12}$ Firstly, Bangladesh has a bureaucratic procedural system and therefore a Labour Court procedure can pose a huge problem besides being a waste of time and money.

2 Faruque, A. A. (2009). Current Status and Evolution of Industrial Relations System in Bangladesh, International Labour Organization. 
Secondly, existing laws in Bangladesh are not adequate and clear. At the point when a modern question emerges, it fathoms the industrial court yet there is no industrial court. ${ }^{13}$

Furthermore, the Annual Report of the Ministry of Labour and Employment showed that only 274 cases have been explained among 14,427 and the rest of the 14,153 cases are still pending since August 2015 in the various Labour Courts of Bangladesh (Annual Report of Ministry of Labour and Employment, 2015). Deficiency of courts for managing work debates; huge cases under various laws uncommon under area 114 of the Code of Criminal Procedure; non-attendance of individuals cause superfluous postponement in discarding cases; visit time petitions related to rehearsing legal advisors and absence of calculated help of the Tribunal are some of the reasons for the build-up of cases in the Labour Tribunal.

Immediately after its independence in 1971, Bangladesh embraced labour laws and arrangements that won amid frontier time and the Pakistani time frame. Notwithstanding, the new legislature of Bangladesh proclaimed a work arrangement in 1972, which prescribed diminishment of exchange union exercises in welfare associations. ${ }^{14}$ The privilege to strike and aggregate bartering in the nationalised ventures was disallowed for half a year by Presidential request no. 55 in May 1972. In 1973, the privilege to strike and lockout, as conceded by the Industrial Relations Organisation (IRO), 1969 was pulled back. In the interim the Emergency Power Ordinance, 1974 was declared and the tenets figured under the Ordinance totally suspended the fair privileges of employees by restricting exchange union exercises, for example, strikes, lock-outs and collective bargaining. ${ }^{15}$

Thirdly, the Labour Law of Bangladesh is a perplexing and inquisitive blend of various enactments, directions and laws. Prior to the appropriation of the Labour Act of 2006, there were around 46 laws in constraint in Bangladesh encompassing work and the

13 Faruque, A. A. (2009). Current Status and Evolution of Industrial Relations System in Bangladesh, International Labour Organization.

14 Labour Policy, (1972). Ministry of Law and Social Welfare, Government of Bangladesh.

15 Md. Abu Taher, (1972). Legal Environment for Industrial Relations in Bangladesh: A Critical Evaluation, the Chittagong University Journal of Law, Vol. 2, 1997, pp. 124-133. 
industrial sector. After the institution of the Labour Act, 25 of the common authorisations were repealed and were amalgamated with the new Code. At the exhibit, there are 21 labour and industrial laws in operation which set up the system for modern relations.

\section{THE BANGLADESH LABOUR ACT, 2006}

The National Labour Law Commission was constituted in 1992 in attempts to modernise labour laws and to expel vulnerabilities and ambiguities in the current laws. ${ }^{16}$ The Commission encircled a questionnaire and sent it to the diverse partners i.e. the businesses, specialists, CBA pioneers, and NGOs to get their perspectives and suggestions for altering the labour laws. The commission presented a report following two years of its constitution. The Commission held interviews with delegates of specialists, pioneers and agents of employers to adequately include them during the time spent remodelling the labour laws in Bangladesh. ${ }^{17}$ The Bangladesh Labour Act 2006 came into existence along these lines on October 11, 2006.

Prior to the institution of the Bangladesh Labour Act, 2006 there were plenty of laws in relation to work. ${ }^{18}$ These laws were established amid the British and Pakistan administration and were observed by many to be insufficient in view of the predominant financial state of Bangladesh. The Act started various changes including enhancing well-being and security issues, issuing of IDs (identification cards) and arrangement letter, enhancing access to equity, ensuring consistency in defining of specialists, youth labour, instalment of pay, upgrading government managed Labour Act, and additional time stipend. ${ }^{19}$

In the field of modern relations, the new Act touched on stipends, insurance to the president, general secretary, arranging secretary and the treasurer of a trade union, who cannot be exchanged starting with one local then onto the next without his/her assent. ${ }^{20}$

16 Md. Abdus Salam, Bangladesh Srama Ain, (2006).O RohitoAinerParthokko, Published by Ministry of Labour and Employment, Government of the People's Republic of Bangladesh.

17 Personal interviews with Mr Syed Sultan Uddin Ahmed and Mr Tapan Datta(See the list of interviewers quoted, Annex).

18 Section 1(3), The Bangladesh Labour Act 2006.

19 Section 1(4), Ibid.

20 Section 1(5), Ibid. 
The law additionally perceives the privilege of the employee in civil aviation and maritime to shape isolated exchange unions. The procedure to shape an aggregate dealing operator has been improved and given that the enlistment of an exchange union might be crossed out on the inability to get 10 for each penny of the aggregate votes in the race. ${ }^{21}$ The exchange union league can fill in as an aggregate bartering operator for a part exchange union when the part exchange union approves the alliance to do as such in its meeting of the official board of trustees. The Act has additionally fortified the part of the Participation Committee to limit strife, and to accomplish harmonious relations. The Act has underscored on the usage of proposals of the Participation Committee. The modern question settlement system has been intricately depicted by specifying time confinement at each stage. ${ }^{22}$

The Bangladesh Labour Act 2006 has been made non-appropriate in specific cases, for example, household specialists. There is likewise no arrangement for holding mollification subsequent to

serving notice for strike or lockout which was accessible in the past Industrial Relations Ordinance (IRO) 1969. ${ }^{23}$

In later years, the International Labour Organization (ILO) Committee of Experts on Conventions and Recommendations have recognized various shortcomings in the Bangladesh Labour Act 2006 with respect to the utilization of the ILO Convention on Freedom of Association and Protection of the Right to Organize, 1947 (No. 87). In its 2009 report, the Committee noted with profound lawmakers that the Act did not contain any enhancements in connection to past enactments and in specific respects contained considerably facilitated limitations which kept running against the arrangements of Convention $87 .{ }^{24}$

\footnotetext{
21 Annual Report of Ministry of Labour and Employment (2013). Ministry of Labour and Employment, Bangladesh.

22 Dhar, N. (2004), Labour and Industrial Laws of Bangladesh (2nd ed.). Dhaka, Bangladesh: Remisi Publishers.

23 Halim, M. A. (2007). The Text Book on Labour and Industrial Law of Bangladesh (1st ed.). Dhaka, Bangladesh: CCB Foundation.

24 International Labour Organization. (2001). Substantive provisions of labour legislation: Settlement of collective labour disputes. Retrieved June 3, 2014

from:http://www.ilo.org/legacy/english/dialogue/ifpdial/llg/noframes/ch4.htm\#1.
} 
The Bangladesh Labour Act, 2006 unmistakably stated that modern debate is esteemed to exist where it is raised by the Collective Bargaining Agent or by the business. However, it does not illuminate the strategy(s) to settle employee related questions where there is no Collective Bargaining Agent. In Bangladesh to influence the Collective Bargaining Agent, and Trade Union is an unquestionable requirement yet in the event that there is no Trade Union then no Collective Bargaining Agent can be framed and for that reason an Industrial Dispute cannot be settled. ${ }^{25}$

\section{CONSTITUTION OF BANGLADESH}

The preface of the Constitution of Bangladesh, 1972, states that the major point of the state should be to acknowledge, through the law based process a communist society, free from abuse; a general public in which the rule of law, principal human rights and opportunity, uniformity and equity, political, monetary and social, will be secured for all citizens ${ }^{26}$. The Fundamental Rights and the Directive Principles of State Policy revered in the Constitution should be particularly stated in view of their pre-eminent significance in coordinating and impacting the Labour Legislation in the nation. ${ }^{27}$

The Fundamental Rights cover inter alia, fairness under the watchful eye of the law; restriction of separation on grounds of religion, race, station, sex or place of birth; equal opportunities in issues of open business; insurance of rights with regards to opportunity of get together and flexibility to frame affiliations; flexibility to hone any calling; assurance of life and individual freedom and ideals from abuse. The Constitution particularly gives as one of the essential rights that all types of constrained work are denied and any contradiction of this arrangement should be an offence culpable as per law. ${ }^{28}$ It additionally perceives opportunity of relationship as a fundamental right. ${ }^{29}$

25 Karim, M. A. (2013). Labour Laws of Bangladesh (1st ed.). Dhaka, Bangladesh: Shufi Prokashoni.

26 Para 3 of the Preamble to the Constitution of the People's Republic of Bangladesh.

27 A. Halim, Text Book on Labour and Industrial Law in Bangladesh, pp. 31.

28 Article 34, The Constitution of the People's Republic of Bangladesh.

29 Article 38, Ibid. 


\section{Importance of the Study}

Individual workers are financially weak. They cannot manage organisations for the security of their rights and despite subsistence pay. Everything considered an institution as insurance in conflict with longer hours of work, unhygienic working conditions, low wages and manhandling is required. The workers are subject to particular risks in worker office mines and other establishments. Everything considered making plans for their prosperity, security and welfare authorisation is required. To extend the consuming vitality of work, sanctioning is vital to empower the advancement of trade unions.

\section{Scope and Limitations of Study}

The discourse will be restricted within the extent of the source and the authentic advancement of labour law of Bangladesh, the issues of labour law of Bangladesh, issues of labour training in Bangladesh, the issues of industrial relations law of Bangladesh and some contextual analysis.

The open door policy for employees to express their grievances at work is seriously restricted. Workers scarcely have learning or the chance of aggregate dealing with their managers. This by no means satisfies the legitimate prerequisites of aggregate dealing specified in the Labour Act. Such a situation is extremely normal in the textile enterprises where casual middlemen attempt to get involved in the grievances of specialists. Without employees' affiliations and tripartite body, specialists regularly neglect to get their grievances settled in the best possible way. All casual parts do not have aggregate haggling among specialists and businesses aside from the development division where the specialists hold dealings with singular contractual workers for their grievances and requests under the Labour Act.

There are a limited number of studies focusing on industrial relations in Bangladesh. Some studies are conducted to change the national system and challenge national laws and regulations regarding industrial relations. Many laws and statutes in Bangladesh with government support are employed in industrial relations. Despite this, new laws are being established and national measures are drawn up to reduce the gap in the system. 


\section{Actors in the IR System}

The idea of industrial relations has a wide significance. The articulation of industrial relations looks at the relationship that develops out of everyday work as well as the relationship between labour and administration. At the point when taken in its more extensive sense, it incorporates the connection between employee and employer over the span of running an industry. ${ }^{30}$ Three main parties are directly involved in industrial relations:

\section{Employers}

Employers have certain rights over employees. They have the privilege to contract and fire them. Management can likewise influence workers' interests by practising their entitlement to migrate, close or union the production line or to present industrial changes.

\section{Employees}

Employees try to enhance the terms and states of their work. They trade sees with the administration and voice their grievances. They likewise need to share basic leadership forces of management. Employees, for the most part, join to shape unions against the management and get bolster from these unions.

\section{Government}

The government impacts and controls industrial relations through laws, rules and agreements and in addition incorporates parties, labour and tribunal courts.

\section{High Involvement of the Government}

One of the principal features of the present modern relations structure in Bangladesh is the central piece of government. In the private zone affiliations, however, the authoritative framework offers principles for the settlement of present-day questions and other management issues at the plant level. The government still holds the capacity to intercede at whatever point(s) without prior consent or talk with the aggravated social affairs. ${ }^{31}$

30 K M Mahmud Hasan, (2008). Causes of Poor Industrial Relations in Bangladesh. Available in online: http://mahmudhasan.com/?p=258.

31 Taher, M., Zaman, M, and Mahmood, M. (1998). The multiplicity of Trade 
The Industrial Relations Regulation Ordinance (IRRO), 1982 stated that the legislature may, whenever, elude any industrial question or workers' grievances to a conciliator or labour court for the settlement of such a debate or proposes measures for a change of such grievances. Despite the fact that this shows that the government is irreversibly and verifiably dedicated to quick and quiet determination of such questions, by and by the distinctions in government courses of action, prohibitive legitimate advances and inappropriate execution of lawful arrangements hinder significantly the viable utilisation and operation of debate settlement techniques. ${ }^{32}$

It was convincingly exhibited that among the legislature blocked (through arbitration) industrial question, almost 89 percent were

settled through an unqualified profit to work for the part of the employees as opposed to by means of a genial arrangement between parties. This primarily occurred because of the coercive part of the legislature and the generally frail union power at the undertaking level. ${ }^{33}$

In spite of the fact that the current laws are relevant in both private and public sector associations, there has additionally been a couple of labour laws particularly identified with open division. Plant level decentralised bartering identified with pay and advantages is restricted in the open division associations and workers' administration terms and conditions vary significantly from those in the private sector. The government singularly decides the compensation and advantages, and open area representatives appreciate nearly preferable professional stability over their partners in the private sector. ${ }^{34}$

In the general population part, the labour administration cannot fire or change any exchange trade union without the government's earlier endorsement. However, in the private sector, businesses can fire any representative, including exchange trade union, giving two months'

Unions in Bangladesh: The Case of Chittagong Port Authority, Journal of Business, Vol.1, No. 3.

32 Alam, F. (1983). Industrial dispute laws in Bangladesh: A study in their development perspectives, The Personnel, Vol. 3, pp. 61-93.

33 Monowar Hossain Mahmood, (2008).Sharing the Pie: Trade Unionism and Industrial Relations in Multinationals in Bangladesh, Sri Lankan Journal of Human Resource Management, Vol.2, No. 1.

34 Khan, F.R. (2006). Compliance: Need of the hour in the apparel industry. Law \& our rights, Issue No. 249. 
notice without need for further clarification. This professional stability arrangement impacts trade union exercises on people in public sector associations and trade union pioneers act politically to indicate arrangements to the political decision-making party. ${ }^{35}$

\section{RECOMMENDATIONS AND CONCLUSION}

Based on the problem of the present study, the researcher suggests the following recommendations:

When any dispute arises, the court procedure takes a long time for a settlement. That is why the court should settle disputes as early as possible because it saves time and money. Although Bangladesh has dealt with some laws in industrial relations, the laws need to be adequate and clear. The Bangladesh Labour Act 2006 has been influenced non-to suitable in particular cases, for instance, family unit authorities. Similarly, there is no course of action for holding conciliations as a result of serving notices for strikes or lockouts which was available in the past Industrial Relations Ordinance 1969. In the years which followed after that, the ILO Committee of Experts on Conventions and Recommendations perceived various inadequacies in the Bangladesh Labour Act 2006 for the usage of the ILO Convention on Freedom of Association and Protection of the Right to Organize, 1947 (No. 87). In its 2009 report, the ILO Committee "noted with significant mourn" that the Act did not contain any improvements in association with past sanctioning and in particular contained extensively encouraged impediments which continued running against the game plans of Convention 87 .

The Bangladesh Labour Act, 2006 unmistakably stated that cuttingedge discussions are said to exist where it is raised by the collective bargaining agent or by the business. However, it does not highlight a system to settle a worker inquiry when there is no collective bargaining agent. In Bangladesh to impact the collective bargaining agent and the trade union is an obvious prerequisite. Nonetheless, if there is no trade union then no collective bargaining agent can be confined and for that reason, an industrial dispute cannot be settled. Bangladesh is a nation which sanctioned 7 ILO traditions out of 8

35 Monowar Hossain Mahmood, (2008). Sharing the Pie: Trade Unionism and Industrial Relations in Multinationals in Bangladesh, Sri Lankan Journal of Human Resource Management, Vol.2, No. 1. 
and those ratified conventions, particularly Conventions 87 and 98 are firmly applicable to one side of the Opportunity of Association and 'Flexibility of Choosing Leadership'. In this way, it is a commitment of our administration to make our national law perfect with ILO traditions. In spite of the government's confirmation of such major quantities of ILO traditions, the new Labour Act of the nation still remains threatening to the specialists, outside purchasers and true business visionaries. Individuals who truly need a stable industrial area in Bangladesh depend on advocates for a Labour Law of universal standard that gives extremely conceivable advantages to specialists and guarantees satisfactory work-related security.

\section{REFERENCES}

A. Halim, Text Book on Labour and Industrial Law in Bangladesh (pp. 31).

Ahmad, M. (1989). Transnational Corporations from Asian and Pacific Developing Economies in Bangladesh. Bangladesh Journal of Political Economy (Vol.19, No. 2, pp. 340-384).

Ahmed, S. (1993). Measures to increase the contribution of vocational training for employment generation and poverty alleviation: The experience of BRAC. Paper presented at the National Seminar on Role of Vocational Training towards Human Resource Development in Bangladesh, Dhaka: 17-20 July.

Akkas, M. A. (1998). Labour management co-operation: The Bangladesh perspectives. Dhaka University Journal of Business Studies, 19(2), 117-145.

Alam, F. (1983). Industrial dispute laws in Bangladesh: A study in their development perspectives, The Personnel (Vol. 3, pp. 61-93).

Annual Report of Ministry of Labour and Employment (2013). Ministry of Labour and Employment, Bangladesh.

Article 34, The Constitution of the People's Republic of Ibid. Bangladesh.

Clark, I., \& Mueller, F. (1996). Organizations and nations: from universalism to institutionalism. British Journal of Management, 7, 125-139.

Coller, X., \& Marginson, P. (1998). Channels of Influences over Employment Practice in MNCs: A case from the food industry. Industrial Relations Journal, 29(1), 4-17. 
Dhar, N. (2004), Labour and industrial laws of Bangladesh (2nd ed.). Dhaka, Bangladesh: Remisi Publishers.

Faruque, A. A. (2009). Current status and evolution of industrial relations system in Bangladesh. International Labour Organization.

Halim, M. A. (2007). The text book on labour and industrial law of Bangladesh (1st ed.). Dhaka, Bangladesh: CCB Foundation.

International Labour Organization. (2001). Substantive provisions of labour legislation: Settlement of collective labour disputes. Retrieved June 3, 2014

K M Mahmud Hasan, (2008). Causes of poor industrial relations in Bangladesh. Retrieved from http://mahmudhasan. $\mathrm{com} / \mathrm{p}=258$.

Karim, M. A. (2013). Labour laws of Bangladesh (1st ed.). Dhaka, Bangladesh: Shufi Prokashoni.

Khan,A.A., \& Taher, M.A. (2008). Human resource management and industrial relations. Dhaka, Bangladesh: Abir Publications.

Khan, F.R. (2006). Compliance: Need of the hour in the apparel industry. Law \& our rights, Issue No. 249.

Khan, M. N. (1996). Labour Administration: Profile on Bangladesh, International Labour Organization Area Office, Dhaka: Bangladesh.

Labour Policy. (1972). Ministry of law and social welfare, Government of Bangladesh.

Md. Abdus Salam, Bangladesh Srama Ain, (2006). O Rohito Ainer Parthokko, Published by Ministry of Labour and Employment, Government of the People's Republic of Bangladesh.

Md. Abu Taher, (1972). Legal environment for industrial relations in Bangladesh: A critical evaluation. The Chittagong University Journal of Law, Vol. 2, 1997, 124-133.

Monowar Hossain Mahmood, (2008). Sharing the pie: Trade unionism and industrial relations in multinationals in Bangladesh, Sri Lankan Journal of Human Resource Management, 2(1).

Personal interviews with Mr Syed Sultan Uddin Ahmed and $\mathrm{Mr}$ Tapan Datta (See the list of interviewers quoted, Annex).

The Bangladesh Labour Act 2006.

Taher, M., Zaman, M, \& Mahmood, M. (1998). The multiplicity of trade unions in Bangladesh: The case of Chittagong port authority, Journal of Business, 1(3).

Talukdar, M. (1996). Labour and industry, Dhaka: Nasa Publishers. 